\title{
Hymenopteran Parasitoids of Leaf Miners (Diptera: Agomyzidae)
}

\author{
N.M. Grigoryan \\ Artsakh State University
}

V.S. Hovhannisyan, A.S. Gasparyan

Armenian State Pedagogical University after Khachatur Abovyan

nonna.grigoryan.88@mail.ru, varugh_zool52@mail.ru, armengasparyan1969@mail.ru

\section{A R T I CLE I N F O}

Keywords:

Hymenoptera,

Agromyzidae,

parasitoid,

wasp,

infestation

\section{A B S T R A C T}

The current article discusses the taxonomic composition of parasitoids and the infestation degree of leaf miners with parasitoids.

The species composition of hymenopteran parasitoids of the Braconidae, Eulophidae and Pteromalidae families is studied and presented for the first time in the Artsakh Republic. Eight parasitoid wasps were reared from the 10 leaf-mining flies which attacked 19 plant species.

\section{Introduction}

Many species of leaf miners (Diptera, Agromyzidae) are serious pests for the cultivated, medicinal and ornamental plant species necessary for humans, and even such species as vegetable leaf miner (L. sativae), tomato leaf miner (L. bryoniae), South American or serpentine leaf miner (L. huidabrensis) and others are considered quarantine species (Spencer, 1989, 1990, Lonsdale, 2011, CABI, 2013, Grigoryan, et al., 2020). As a result of climate changes observed in recent years, as well as the import of new types of cultivated and ornamental plants in open and covered soils, the habitats of leaf miners and the intensity of infection are noticeably increasing. Based on the degree of damage caused by mining flies, various pesticides are often used against plant pests in many countries, which generally do not have a selective effect.
Repeated application of pesticides also destroys useful entomofauna, including the natural enemies of leaf miners, which play an important role in influencing the number of pests. In addition, leaf miners gain a high tolerance through the multiple use of chemicals (Keil, et al., 1985).

The most effective method of controlling leaf miners is the use of natural enemies, such as pathogenic bacteria, parasitoids and insect predators, which are also harmless to the environment (Shojaey, et al., 2020). Based on the undesirable consequences of chemical control in recent years, in many countries, including Artsakh, much attention has been paid to the research of the natural enemies of leaf miners. Therefore, our main purpose was to study the parasitoids' species diversity of mining flies in Artsakh. The species diversity of the family Eulophidae (Hymenoptera) and the peculiarities of their parasitism 
were studied by Askew and Shaw in England (Askew and Shaw, 1974). Recently, the species composition of subfamilies Eulophinae, Entedoninae and Tetrastichinae has been studied in Iran (47 species) (Yefremova, et al., 2007), 17 species of ecto- and endoparasitoids of chalcidoid parasites (Hymenoptera, Eulophidae) have been explored in the Middle Volga River Basin (Strakhova, et al., 2013), while 15 species of hymenopterous parasitoids were found in northwestern Iran (Iranian Azerbaijan) in 2015, 3 of which belong to the Braconidae family, 10 - to the Eulophidae family, 2 - to the Pteromalidae (Lotfalizadeh, et al., 2015). As a result of research in 2020 , the entomofauna of Iran was added with new parasitic species of the family Pteromalidae (Shojaey, et al., 2020).

It has been confirmed that parasitoids play an essential role in the regulation of leaf miners' number in nature. Hymenoptera is considered one of the largest orders of insects with huge species diversity. More than two dozen families of the order, such as Ichneumonidae, Braconidae, Sphecidae, Pteromalidae and others, parasitize insects and pests reducing their numbers in nature. Larvae of hymenopteran parasitoids having developed through the early instar larvae of host insects gradually destroy them. This is one of the important features that distinguish parasitoids from parasites (Askew, 1971), which do not kill their hosts. Parasitoid larvae can live inside host organism (endoparasitoid) or outside the host organism (ectoparasitoid).

Noyes J. (2004) recorded 300 species of parasitoids, more than 80 of which parasitize leaf miners of the genus Liriomyza (Diptera: Agromyzidae). The complexity of the study of leaf miners' parasitofauna occurs during pupation when their larvae come out of the mines, taking with them the chalcid parasitoids (Askew and Shaw, 1974).

Our task was to detect the leaf miner pupae infested with parasitoids and rear adult parasitic species, to conduct structural research for precise differentiation, to study the biological and ecological features of the parasitoids' development as well as the character and rate of infestation.

\section{Materials and methods}

The research material was leaves infected with leaf miners and collected from different regions of Artsakh Republic for the periods of April 2018 to August 2020. The infected leaves were stored in glass tubes, filled with wet sand $\left(23-25^{\circ} \mathrm{C}\right)$ until pupae formation. Usually the development of the larva lasts $4-5$ days $\left(23-25^{\circ} \mathrm{C}\right)$, pupal development takes $7-14$ days $\left(25-28^{\circ} \mathrm{C}\right)$. Prolonged pupal development is associated with the formation of mold or with the development of natural enemies inside leaf miner pupa, which usually lasts 10 - 20 days. We separated the infested pupae, moved them to another vial $\left(25-28^{\circ} \mathrm{C}\right.$, $70 \pm 5 \% \mathrm{RH}$ ) and constantly followed the development process. After 24 hours the emerged adult parasitoids were stored in $75 \%$ ethyl-alcohol for future work. Species were classified according to the accepted taxonomic classification (Boucek, 1988), and various identification guides were used to differentiate morphological features (Hansson, 1985, Graham, 1959, LaSalle and Parella, 1991, Achterberg, 1993, Shaw, 1991). Morphological studies of parasitoids were carried out in the Biological Research Laboratory of Artsakh State University using XSZ-0800 and ADSM302 digital microscopes.

\section{Results and discussions}

As a result of our research, in Artsakh Republic we found 8 parasitoid species belonging to 8 genera, 6 subfamilies and 3 families: Braconidae (2 species), Eulophidae (4 species) and Pteromalidae ( 2 species) (Table 1$)$. If the development of uninfected pupae at a temperature of $25-28^{\circ} \mathrm{C}$ takes 7-14 days, then the development of infested pupae takes longer, about 10-20 days.

Most species of Braconidae family (Hymenoptera: Ichneumonoidea) are endo- and ectoparasitoids of eggs and larvae. A number of parasitoids of this family are isolated from the host organism at the end of the development cycle to complete development beyond it (Shaw and Huddleston, 1991). Family Braconidae is represented by two subfamilies: Opiinae, Blanchard, 1845 and Alysiinae, Leah, 1815, which are endoparasitoids. The development of leaf miners' larvae infested with parasitoids is not interrupted, their larvae continue to feed and mature, and even pupate. The development of parasitoids ends inside host larvae and pupae, and the adult braconid emerges from the pupa (Li, et al., 2013).

Species of the family Eulophidae (Hymenoptera: Chalcidoidea) are widely distributed and are considered ectoparasitoids of larvae and pupae. The family includes 290 genera and 4300 species (Noyes, 2001).

Family Pteromalidae (Hymenoptera: Chalcidoidea) is one of the largest families of the Chalcidoidea superfamily, numbering 3500 species and 600 genera (Noyes, 2002, 2003). Parasitic pteromalids lay eggs inside hosts' eggs, larvae and pupae. It should be noted that at the embryonic stage, the infested leaf miners' development is not interrupted and continues until the formation of larva, then pupa, where the development of leaf miners is ceased and the adult parasitic wasp emerges from pupa. 
Table 1 shows the species composition of mining flies, which attack various plant species, and their parasitoids.
The following table (Table 2) shows the number of parasitoids developing in different species of mining flies on one plant.

Table 1. Taxonomic composition of the studied parasitic wasps*

\begin{tabular}{|c|c|c|c|c|c|c|}
\hline $\begin{array}{l}\text { Super- } \\
\text { family }\end{array}$ & Family & Subfamily & Genus & Species & $\begin{array}{l}\text { Host species } \\
\text { of mining flies }\end{array}$ & Infected plant species \\
\hline \multirow{12}{*}{ 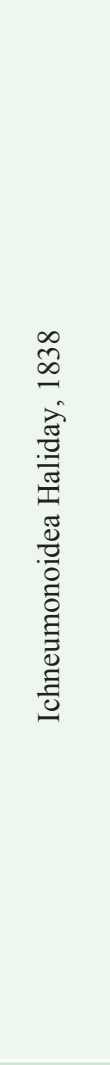 } & \multirow{12}{*}{ 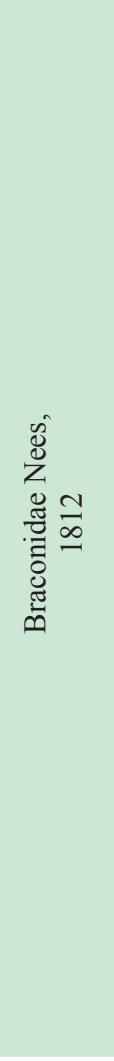 } & \multirow{8}{*}{$\begin{array}{l}\text { Opiinae } \\
\text { Blanchard, } \\
1845\end{array}$} & \multirow{8}{*}{$\begin{array}{l}\text { Opius Wesmael, } \\
1835\end{array}$} & \multirow{8}{*}{ Opius sp. } & $\begin{array}{l}\text { Phytomyza horticola } \\
\text { (Goureau, 1851) }\end{array}$ & $\begin{array}{c}\text { Cardaria draba (L.) Desv. } \\
\text { (Brassicaceae) }\end{array}$ \\
\hline & & & & & \multirow[t]{3}{*}{$\begin{array}{l}\text { Liriomyza bryoniae } \\
\text { (Kaltenbach, 1858) }\end{array}$} & $\begin{array}{l}\text { Capsicum annuum L. } \\
\text { (Solanaceae) }\end{array}$ \\
\hline & & & & & & $\begin{array}{l}\text { Phaseolus vulgaris L. } \\
\text { (Fabaceae) }\end{array}$ \\
\hline & & & & & & $\begin{array}{l}\text { Cucurbita pepo L. } \\
\text { (Cucurbitaceae) }\end{array}$ \\
\hline & & & & & $\begin{array}{c}\text { Calycomyza } \\
\text { humeralis } \\
\text { (von Roser, 1840) }\end{array}$ & $\begin{array}{l}\text { Erigeron canadensis L. } \\
\text { (=Conyza canadensis }(\mathrm{L} .)\end{array}$ \\
\hline & & & & & $\begin{array}{l}\text { Phytomyza lappae } \\
\text { (Goureau, 1851) }\end{array}$ & $\begin{array}{l}\text { Arctium lappa L. } \\
\text { (Asteraceae) }\end{array}$ \\
\hline & & & & & \multirow{2}{*}{$\begin{array}{l}\text { Amauromyza leonuri } \\
\text { (Spencer, 1971) }\end{array}$} & $\begin{array}{l}\text { Ballota nigra L. } \\
\text { (Lamiaceae) }\end{array}$ \\
\hline & & & & & & $\begin{array}{l}\text { Lamium album } \mathrm{L} . \\
\text { (Lamiaceae) }\end{array}$ \\
\hline & & \multirow{4}{*}{$\begin{array}{c}\text { Alysiinae Leah, } \\
1815\end{array}$} & \multirow{4}{*}{$\begin{array}{c}\text { Chaenusa } \\
\text { seminervata van } \\
\text { Achterberg, } 2012\end{array}$} & \multirow{4}{*}{$\begin{array}{l}\text { Chaenusa } \\
\text { seminervata sp. }\end{array}$} & $\begin{array}{l}\text { Liriomyza congesta } \\
\text { (Becker, 1903) }\end{array}$ & $\begin{array}{l}\text { Trifolium repens L. } \\
\text { (Fabaceae) }\end{array}$ \\
\hline & & & & & $\begin{array}{l}\text { Liriomyza endiviae } \\
\text { (Hering, 1955) }\end{array}$ & $\begin{array}{l}\text { Lactuca sativa L. } \\
\text { (Asteraceae) }\end{array}$ \\
\hline & & & & & $\begin{array}{l}\text { Phytomyza horticola } \\
\text { (Goureau, 1851) }\end{array}$ & $\begin{array}{l}\text { Raphanus sativus L. } \\
\text { (Brassicaceae) }\end{array}$ \\
\hline & & & & & $\begin{array}{c}\text { Phytomyza plantaginis } \\
\text { (Robineau-Desvoidy, } \\
1851 \text { ) }\end{array}$ & $\begin{array}{l}\text { Plantago major L. } \\
\text { (Plantaginaceae) }\end{array}$ \\
\hline \multirow{8}{*}{$\begin{array}{l}\frac{\pi}{0} \\
\frac{0}{0} \\
\frac{0}{0} \\
\frac{0}{\pi} \\
\frac{\pi}{0}\end{array}$} & \multirow{6}{*}{ 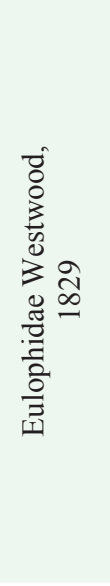 } & $\begin{array}{l}\text { Eulophinae } \\
\text { Westwood, } \\
1829\end{array}$ & $\begin{array}{c}\text { Diglyphus Walker, } \\
1844\end{array}$ & $\begin{array}{l}\text { Diglyphus isaea } \\
\text { (Walker, 1838) }\end{array}$ & $\begin{array}{l}\text { Liriomyza endiviae } \\
\text { (Hering, 1955) }\end{array}$ & $\begin{array}{l}\text { Lactuca sativa L. } \\
\text { (Asteraceae) }\end{array}$ \\
\hline & & \multirow{5}{*}{$\begin{array}{l}\text { Entedoninae } \\
\text { Forster, } 1856\end{array}$} & \multirow{3}{*}{$\begin{array}{c}\text { Pediobius Walker, } \\
1846\end{array}$} & \multirow{3}{*}{$\begin{array}{l}\text { Pediobius } \\
\text { metallicus } \\
(\text { Nees, 1834) }\end{array}$} & \multirow{3}{*}{$\begin{array}{l}\text { Phytomyza horticola } \\
\text { (Goureau, 1851) }\end{array}$} & $\begin{array}{l}\text { Dahlia pinnata Cav. } \\
\text { (Asteraceae) }\end{array}$ \\
\hline & & & & & & $\begin{array}{l}\text { Sisymbrium loeselii L. } \\
\text { (Brassicaceae) }\end{array}$ \\
\hline & & & & & & $\begin{array}{c}\text { Galinsoga parviflora Cav. } \\
\text { (Asteraceae) }\end{array}$ \\
\hline & & & $\begin{array}{l}\text { Neochrysocharis } \\
\text { Kurdjumov, } 1912\end{array}$ & $\begin{array}{l}\text { Neochrysocharis } \\
\text { sp. }\end{array}$ & $\begin{array}{l}\text { Phytomyza horticola } \\
\text { (Goureau, 1851) }\end{array}$ & $\begin{array}{l}\text { Leucanthemum maximum } \\
\text { Ramond (DC.) } \\
\text { (Asteraceae) }\end{array}$ \\
\hline & & & $\begin{array}{l}\text { Apleurotropis } \\
\text { Girault, } 1913\end{array}$ & Apleurotropis sp. & $\begin{array}{l}\text { Phytomyza horticola } \\
\text { (Goureau, 1851) }\end{array}$ & $\begin{array}{c}\text { Alliaria petiolata (Bieb.) } \\
\text { Cavara et Grande } \\
\text { (Brassicaceae) }\end{array}$ \\
\hline & 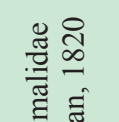 & $\begin{array}{l}\text { Pteromalinae } \\
\text { Dalman, } 1820\end{array}$ & $\begin{array}{l}\text { Nasonia vitripennis } \\
\text { (Walker, 1836) }\end{array}$ & Nasonia sp. & $\begin{array}{l}\text { Amauromyza } \\
\text { flavifrons } \\
\text { (Meigen, 1830) }\end{array}$ & $\begin{array}{l}\text { Saponaria officinalis L. } \\
\text { (Asteraceae) }\end{array}$ \\
\hline & 这泀 & $\begin{array}{l}\text { Miscogastrinae } \\
\text { Walker, } 1833\end{array}$ & $\begin{array}{l}\text { Halticoptera } \\
\text { Spinola, } 1811\end{array}$ & Halticoptera sp. & $\begin{array}{l}\text { Liriomyza bryoniae } \\
\text { (Kaltenbach, 1858) }\end{array}$ & $\begin{array}{l}\text { Beta vulgaris L. } \\
\text { (Amaranthaceae) }\end{array}$ \\
\hline
\end{tabular}

*Composed by the authors. 
Table 2. Parasitoids of leaf-mining flies of the family Agromyzidae**

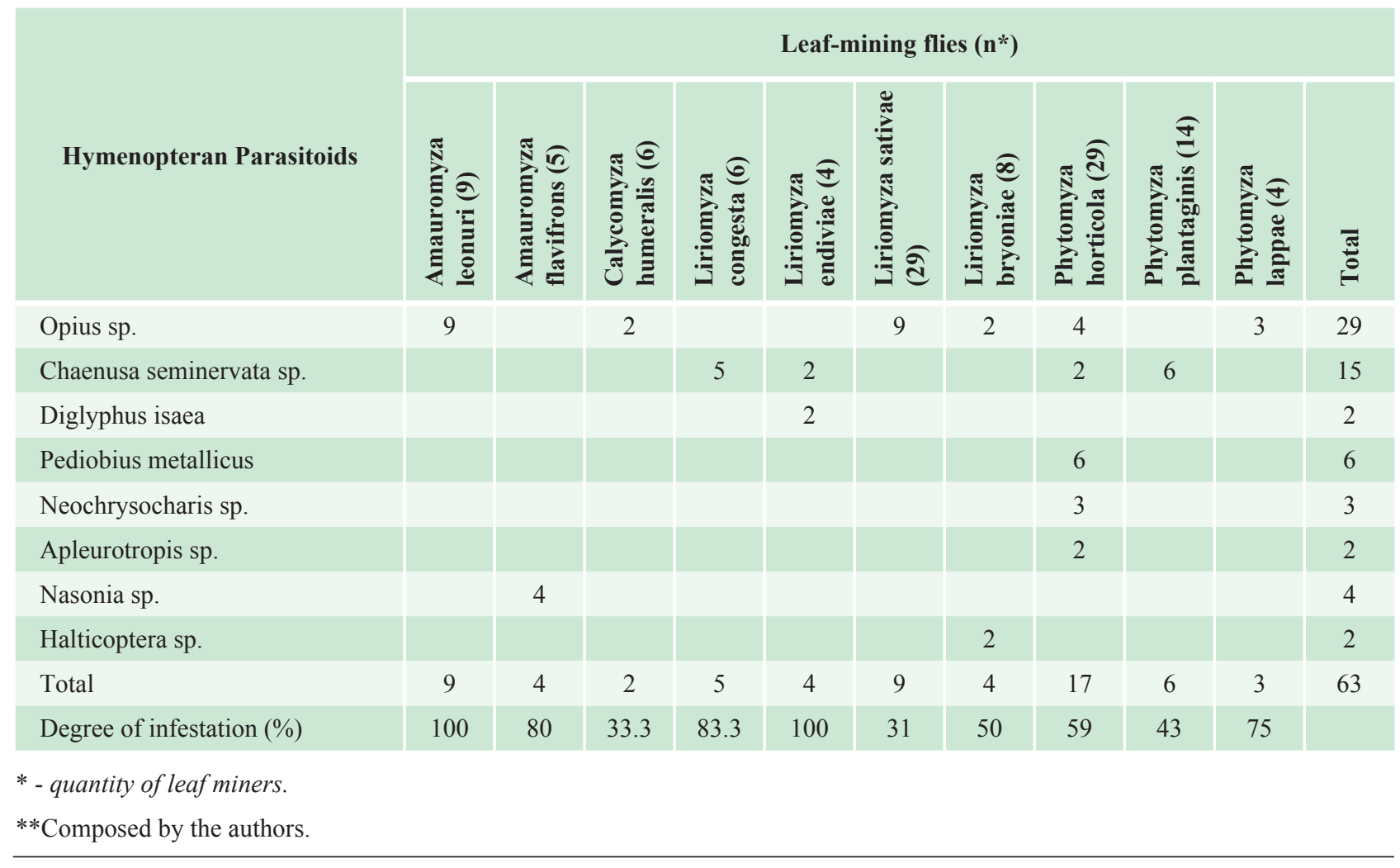

The most common parasitoids of the Braconidae family are the species Opius sp. (46\%) and Chaenusa seminervata sp. $(24 \%)$ (Figure 1), which together makes up $70 \%$ of parasitoids. A large number of parasitoids were reared from $\mathrm{Ph}$. horticola $(27 \%)$. A relatively large amount of Opius sp. was reared from the species of Am. leonuri and L. sativae, whose infestation is $100 \%$ and $31 \%$, respectively.

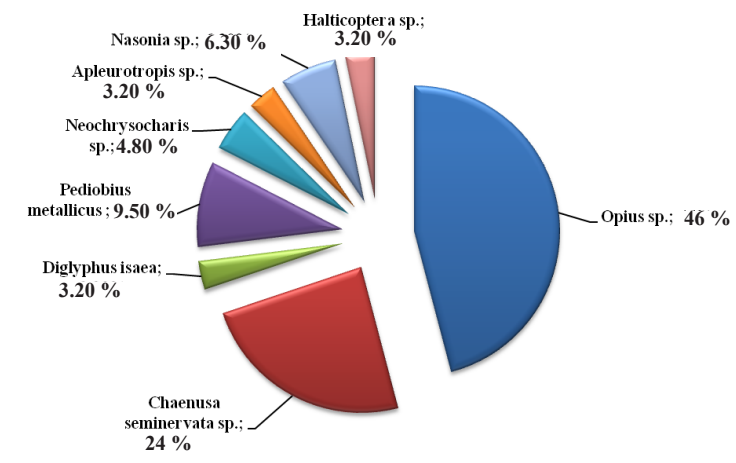

Figure 1. Quantitative ratio of parasitoids (composed by the authors).

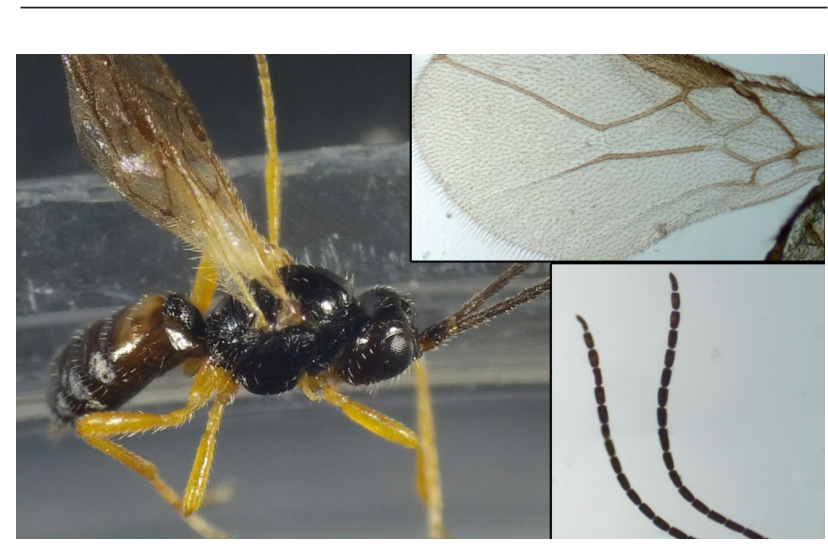

Genus Opius Wesmael, 1835 Opius sp.

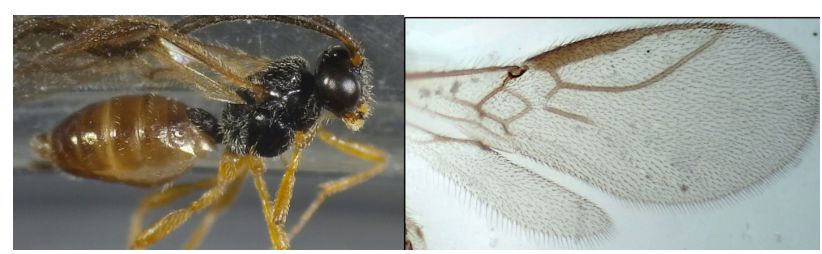

Genus Chaenusa seminervata van Achterberg, 2012 Chaenusa seminervata sp.

Figure 2. Family Braconidae Nees, 1812. 


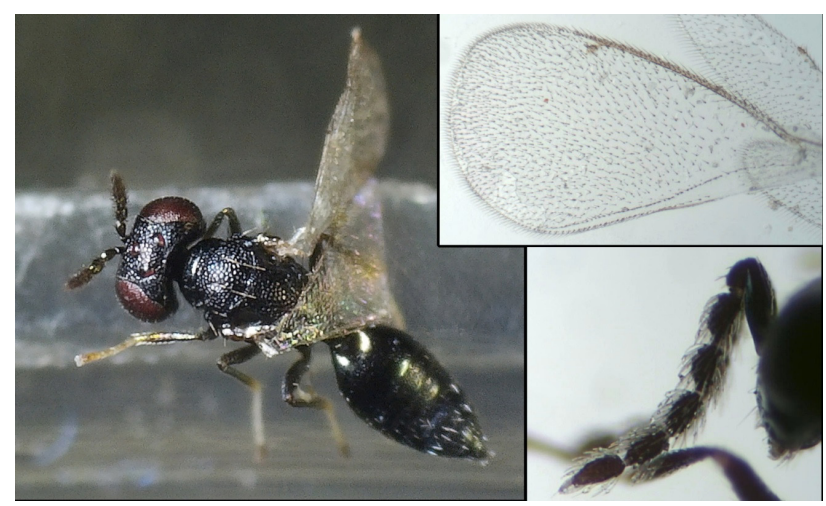

Genus Pediobius Walker, 1846 Pediobius metallicus (Nees, 1834)
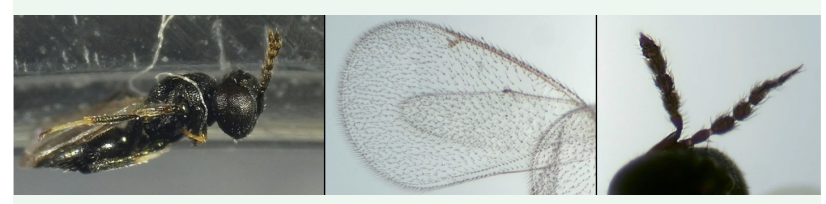

Genus Diglyphus Walker, 1844 Diglyphus isaea (Walker, 1838)

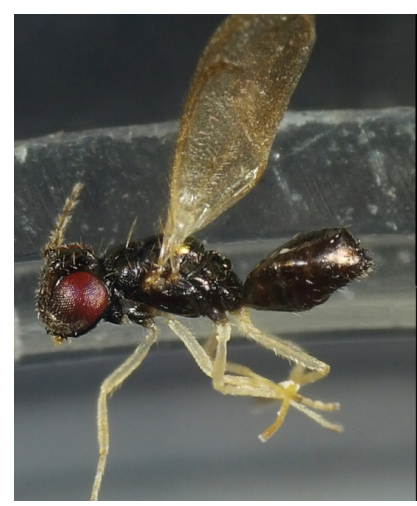

Genus Apleurotropis Girault, 1913

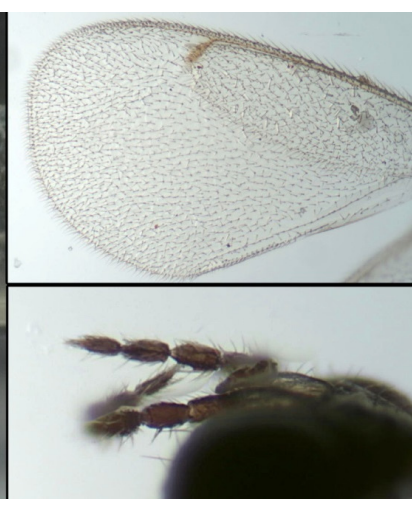

Apleurotropis sp.

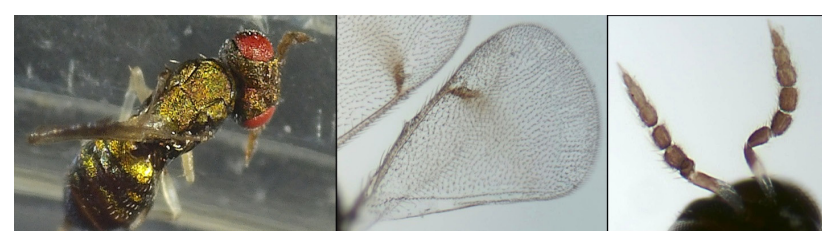

Genus Neochrysocharis Kurdjumov, 1912 Neochrysocharis sp.

Figure 3. Family Eulophidae Westwood, 1829.

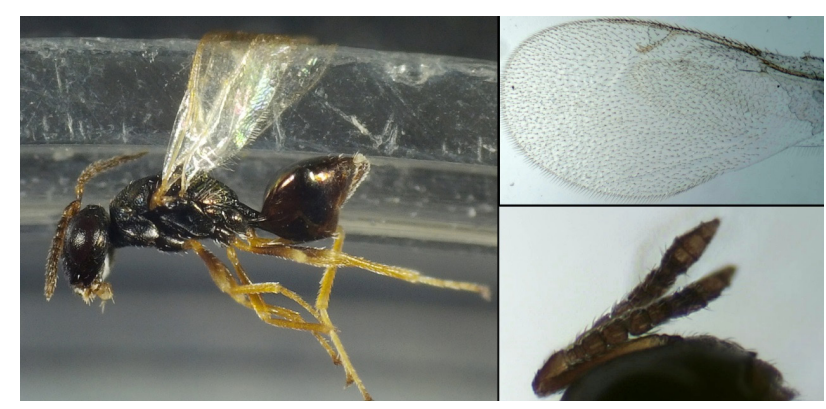

Genus Nasonia vitripennis, Walker, 1836 Nasonia sp.

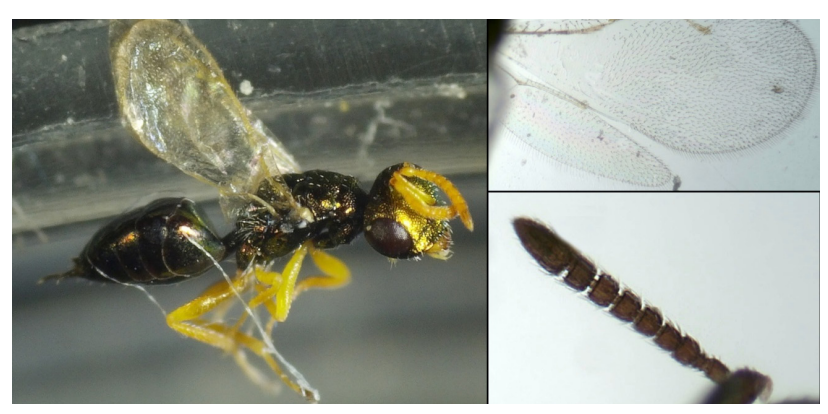

Genus Halticoptera Spinola, 1811 Halticoptera sp.

Figure 4. Family Pteromalidae Dalman, 1820.

The infestation rate of $L$. congesta parasitized by Chaenusa seminervata sp. is $83.3 \%$, and the infestation rate of Ph. plantaginis is $43 \%$.

It can be noted that specialized parasitoids are more effective in regulating the number of leaf miners than nonspecialized species with a density of less than $10 \%$.

We have also presented the reared parasitic species of the Braconidae (Figure 2), Eulophidae (Figure 3) and Pteromalidae families (Figure 4).

\section{Conclusion}

During the research, we found 8 species of parasitoids belonging to the Braconidae, Eulophidae and Pteromalidae families, which parasitize the species of the families Amauromyza, Calycomyza, Liriomyza and Phytomyza. Species of Braconidae family (Opius sp. - $46 \%$, Chaenusa seminervata sp. - $24 \%$ ) have a high occurrence rate, but the Eulophidae family stands out with its species diversity. 5 parasitic species were reared from the polyphagous $\mathrm{Ph}$. horticola species, which is considered as a pest of cucurbits and ornamental plants. Considering the high rate of parasitism, we can assume that parasitic species play an important role in regulating the number of mining flies. As above-mentioned, when we use pesticides against leaf-mining flies, it is necessary to take into account that in order to preserve important fauna, we should also know the infestation period and development features of parasitic wasps. 


\section{References}

1. Achterberg, C. (1993). Illustrated Key to the Subfamilies of the Braconidae (Hymenoptera: Ichneumonoidea). Zoologische Verhandelingen, 283, - pp. 1-189.

2. Askew, R.R. (1971). Parasitic Insects // London, - 316 p.

3. Askew, R.R., Shaw, M.R. (1974). An Account of the Chalcidoidea (Hymenoptera) Parasitizing Leaf-Mining Insects of Deciduous Trees in Britain // Biol. J. of the Linnean Society. V. 6, - pp. 289-335.

4. Boucek, Z. (1988). Australasian Chalcidoidea (Hymenoptera). A Biosystematic Revision of Genera of Fourteen Families, with a Reclassification of Species // CAB International, UK, - $832 \mathrm{p}$.

5. CABI. Crop Protection Compendium // Wallingford, UK, CABI. 2013, available at https://www.cabi.org/cpc (accessed on October 27, 2021).

6. Graham, M.W.R. de V. (1959). Keys to the British Genera and Species of Elachertinae, Eulophinae, Entedoninae and Euderinae (Hymenoptera, Chalcidoidea) // Transactions of the Society for British Entomology 13 (10), - pp. 169-204.

7. Grigoryan, N.M., Hovhannisyan, V.S., Galstyan, H.G. (2020). The Study of Agricultural Pests of the Genus Liriomyza (Diptera: Agromyzidae) in Nagorno-Karabakh. Samara Journal of Science. - Vol. 9. Iss.3, - pp. 37-43. DOI:10.17816/snv202093106 (in Russian).

8. Hansson, C. (1856). Taxonomy and Biology of the Palaearctic Species of Chrysocharis Förster (Hymenoptera: Eulophidae) // Entomologica Scandinavica (supplement). V. 26, - pp. 1-130.

9. Keil, C.B., Parrelia, M.P., Morse, J.G. (1985). Method for Monitoring and Establishing Baseline Data for Resistance to Permethrin by Liriomyza trifolii (Burgess) // J. Econ. Entomol., 78, - pp. 419-422.

10. LaSalle, J., Parella, M.P. (1991). The Chalcidoid Parasites (Hymenoptera, Chalcidoidea) of Economically Important Liriomyza Species (Diptera, Agromyzidae) in North America // Proceedings of the Entomological Society of Washington. - V. 93. - № 3, - pp. 571-591.

11. Li, X.Y., van Achterberg, C. \& Tan, J.C. (2013). Revision of the Subfamily Opiinae (Hymenoptera, Braconidae) from Hunan (China), Including Thirty-Six New Species and Two New Genera // ZooKeys, 268, -pp. 1-168. http:// dx.doi.org/10.3897/zookeys.268.4071.

12. Lonsdale, O. (2011). The Liriomyza (Agromyzidae: Schizophora: Diptera) of California // Zootaxa, 2850, - pp. 1-123.
13. Lotfalizadeh, H., Pourhaji, A., Zargaran, M.R. (2015). Hymenopterous Parasitoids (Hymenoptera: Braconidae, Eulophidae, Pteromalidae) of the Alfalfa Leafminers in Iran and their Diversity // Far Eastern Entomologist, - N 288, - pp. 1-24.

14. Noyes, J.S. (2001). Chalcidoidea // Electronic Publication (CD-ROM). Taxapad, Dicky S. Yu, Bentall Centre, Vancouver, Canada.

15. Noyes, J.S. (2002). Interactive Catalogue of World Chalcidoidea (2001 - Second Edition) // CD-Rom. Taxapad and the Natural History Museum, London, UK.

16. Noyes, J.S. (2003). Universal Chalcidoidea Database // World Wide Web Electronic Publication, available at https://www.nhm.ac.uk/our-science/data/chalcidoids/ (accessed on October 25, 2021).

17. Noyes, J. S. (2004). Universal Chalcidoidea Database. The Natural History Museum, available at https://www. nhm.ac.uk/our-science/data/chalcidoids/ (accessed on October 27, 2021).

18. Shaw, M.R., Huddleston, T. (1991). Classification and Biology of Braconid Wasps (Hymenoptera: Braconidae) // Handbooks for the Identification of British Insects, - Vol. 7, Part 11, - pp. 16-96.

19. Shojaey, M., Khayrandish, M., Madjdzadeh, S. M., Lotfalizadeh, H. (2020). A Faunistic Study of Miscogastrinae, Ormocerinae and Spalangiinae (Chalcidoidea: Pteromalidae) in South of Kerman Province with a New Generic Record from Iran // Journal of Insect Biodiversity and Systematics, - 6 (2), - pp. 167-177.

20. Spencer, K.A. (1989). Leaf Miners. Plant Protection and Quarantine // In R.P. Kahn, Vol. 2, Selected Pests and Pathogens of Quarantine Significance, Boca Raton, FL, CRC Press, - pp. 77-98.

21. Spencer, K.A. (1990). Host Specialization in the World Agromyzidae (Diptera) // Series Entomologica, - Vol. 45. Kluwer Academic Publishers, Dordrecht, - 444 p.

22. Strakhova, I. S., Yefremova, Z. A., Tschirnhaus, M. von, Yegorenkova, E. N. (2013). Parasitoid Complex (Hymenoptera, Eulophidae) of Mining Flies (Diptera, Agromyzidae) in the Middle Volga River Basin // Zoologicheskii Zhurnal [Zoological Journal], - Vol. 92, - № 5, - pp. 553-561. DOI: 10.7868/S0044513413050085 (in Russian).

23. Yefremova, Z., Ebrahimi, E., Yegorenkova, E. (2007). The Subfamilies Eulophinae, Entedoninae and Tetrastichinae in Iran, with Description of New Species (Hymenoptera: Eulophidae) // Entomofauna, Zeitschrift Für Entomologie, Ansfelden/Austria, - Band 28, Heft 25, - pp. 321-356. 